\title{
Comparison Of Heavy Metal Absorption Of Some Algae Isolated From Altınapa Dam Lake (Konya)
}

\author{
Numan Emre GÜMÜŞ * Baran AȘIKKUTLU ${ }^{2} \quad$ Hatice Banu KESKINKKAYA ${ }^{2}$ Cengiz AKKÖZ ${ }^{2}$ \\ ${ }^{I}$ Karamanoğlu Mehmetbey University, Scientific and Technological Research and Application Center, 70200 Karaman, Turkey \\ ${ }^{2}$ Selçuk Universty, Department of Biology, Faculty of Science, Campus, 42100 Konya, Turkey
}

How to cite: Gümüş, N.E., Aşıkkutlu, B., Keskinkaya, H.B. \& Akköz, C. (2021). Comparison Of Heavy Metal Absorption Of Some Algae Isolated From Altınapa Dam Lake (Konya). J. Anatolian Env. and Anim. Sciences, 6(1), 50-56.

Atıf yapmak için: Gümüş, N.E., Aşıkkutlu, B., Keskinkaya, H.B. \& Akköz, C. (2021). Altınapa Baraj Gölü’nden (Konya) İzole Edilen Bazı Alglerin Ağır Metal Absorpsiyonlarının Karşılaştırılması. Anadolu Çev. ve Hay. Dergisi, 6(1), 50-56.

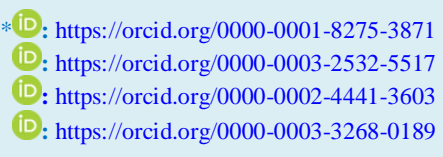

*Corresponding author's: Numan Emre GÜMÜŞ Karamanoğlu Mehmetbey University, Scientific and Technological Research and Application Center, 70200 Karaman, Turkey. 凶: numanemregumus@kmu.edu.tr

\begin{abstract}
Today, due to the intense pollution in water resources, clean water shortage is experienced in most regions. In order to remove the pollution from waters, many studies are carried out using algae with high metal absorption capacity. In our study, benthic algae samples from different habitats (epipelic, epiphytic and epilitic) were taken from the Altınapa Dam Lake in Konya, in order to study the potentials of heavy metal removal. Some microalgae were isolated from the samples and heavy metal absorption capacities were examined among the pure cultures obtained. Biosorption properties were tried to be determined in samples taken at 5, 10, 20, 45, 60, 90 and 120 minutes by exposing Chlorochytrium paradoxum, Haematococcus lacustris and Scenedesmus circumfusus species to heavy metals of $\mathrm{Cu}$ and $\mathrm{Mn}$. Scenedesmus circumfusus species reached the best absorption capacity for both $\mathrm{Cu}$ and $\mathrm{Mn}$ metals. According to this research, the algae we studied are of the opinion that they can be used to increase the efficiency and selectivity of heavy metal biosorption.
\end{abstract}

Keywords: Algae, biosorption, heavy metal, isolation.

\author{
*Sorumlu yazar: \\ Numan Emre GÜMÜS \\ Karamanoğlu Mehmetbey Üniversitesi, \\ Bilimsel ve Teknolojik Araştırma ve \\ Uygulama Merkezi, 70200 Karaman, \\ Türkiye. \\ 凶: numanemregumus@kmu.edu.tr
}

\section{Altınapa Baraj Gölü’nden (Konya) İzole Edilen Bazı Alglerin Ă̆ır Metal Absorpsiyonlarının Karşılaştırılması}

Öz: Günümüzde su kaynaklarında meydana gelen yoğun kirlilik nedeniyle, çoğu bölgede temiz su sıkıntısı yaşanmaktadır. Sularda oluşan kirliliğin giderilmesi için ağır metal absorpsiyon kapasitesi yüksek olan alglerin kullanıldığı birçok çalışma yapılmaktadır. Araştırmamızda ağır metal giderimi potansiyellerini çalışabilmek için, Konya' da bulunan Altınapa Baraj Gölü’nden değişik habitatlardan (epipelik, epifitik ve epilitik) bentik alg örnekleri alınmıştır. Alınan örneklerden bazı algler izole edilmiş ve elde edilen saf kültürler arasında ağır metal absorpsiyon kapasiteleri incelenmiştir. Chlorochytrium paradoxum, Haematococcus lacustris ve Scenedesmus circumfusus türleri $\mathrm{Cu}$ ve $\mathrm{Mn}$ ağır metallerine maruz bırakılarak 5. 10. 20. 30. 45. 60.90 ve 120. dakikalarda alınan örneklerde biyosorpsiyon özellikleri tespit edilmeye çalışılmıştır. Hem $\mathrm{Cu}$ Hem Mn metallerinde en iyi absorblama kapasitesine Scenedesmus circumfusus türü ulaşmıştır. $\mathrm{Bu}$ araştırmaya göre; çalıştığımız algler, ağır metal biyosorpsiyonunun etkinliğini ve seçiciliğini artırmak için kullanılabilir olduğu düşüncesindeyiz.

Anahtar kelimeler: Ağır metal, alg, biyosorpsiyon, izolasyon. 


\section{INTRODUCTION}

Surface water sources such as lakes, streams, dams and agricultural waters; It is very important for public health, the continuity of the aquatic ecosystem and agricultural activities (Noori et al., 2018). Trace element pollution in the aquatic environment has become a global concern due to its potential harmful effects on aquatic ecosystems and human health. Heavy metals can contaminate water bodies through natural deposits, mining waste, industrial and agricultural activities. The water contaminated with trace metals may not be suitable for human and animal drinking, irrigation, protection of aquatic ecosystems, recreation and aquaculture (Kibria, 2016).

Wastes generated in regions with high industrial and urban development are important sources of pollution for aquatic environments (Çoğun \& Kargın, 2020). Water pollution, which has a negative impact on the quality of life of the society, is becoming threatening to human health day by day (Gemici et al., 2019). To provide a locally controlled water supply, wastewater recycling offers great environmental benefits. Recycling of water prevents the consumption of water from ecosystems and the reduction of environmental pollution and the accumulation of pollutants in our ecosystem. With the scarcity of fresh water resources and the pollution in the ecosystem, industrial wastewater increases the importance of wastewater treatment. Extensive research is being conducted to develop an effective technology to overcome the toxicity and negative environmental effects of heavy metals and ionic forms (Nazal, 2019). Algae are eutrophic and eukaryotic organisms that play an important role in the food, pharmaceutical, cosmetic, fuel and textile industries. These are an essential part of our ecosystem and can help control the growing pollution problem. It is known that algae are a good indicator of pollution level in aquatic ecosystems (Dora et al., 2010). These biological properties make algae a very good "early warning system". Moreover, green algae have also been reported to be suggested for phytoremission of some elements (Gomes \& Asaeda 2013; Olal, 2016; Sahu et al., 2020). Algae can be used to improve the efficiency and selectivity of heavy metal biosorption (Cheng et al., 2019). With the excessive contamination of aquatic ecosystems with human-induced pollutants such as heavy metals and the increase in potential toxic effects of these pollutants on living things, studies on metal accumulation in algae gain importance day by day. Due to the fact that algae are important parts of the aquatic food web, the number of studies to evaluate the toxic damage of heavy metals to these creatures has increased in recent years (Şentürk, 2018a).

The health effects of various heavy metals have raised awareness of the health risk associated with heavy metals worldwide. For this reason, researchers around the world have worked on different technologies to remove heavy metals from the environment. Biosorption has emerged as a promising alternative to traditional methods (Richards et al., 2019). In addition to biosorption, different physicochemical mechanisms include microprecipitation, chelation, ion exchange, and physical adsorption. Many studies are trying to identify suitable biosorbents that can effectively remove heavy metals. These biosorbents typically include agricultural waste, plant-based adsorbents, algae, fungi, and bacteria (Poo et al., 2018). Industrial and urban wastewater can be used as a food source for algae production. Wastewater is an ideal environment for algae growth as they contain high amounts of nitrogen and phosphorus (Knezevic, 2016).

Among the biosorbents, algae-based biosorbents have been the focus of attention due to their renewability, superior uptake capacity, absence of toxic waste generation, low cost, time and energy savings, year-round occurrence, ease of use, and great abundance in the sea. Following the biosorption process, the remaining algal biomass can be dumped into municipal landfills with a much lower environmental footprint (Yu et al., 2017; Poo et al., 2018).

In this study, it is aimed to compare the copper $(\mathrm{Cu})$ and Manganese (Mn) metal absorption capacities of the microalgae samples taken from Altınapa Dam Lake in Konya. The advantages of algae such as having high metal holding capacity from wastewater and being economical and easily available are taken into consideration. Scenedesmus circumfusus Hortobágyi, Chlorochytrium paradoxum (G.A.Klebs) G.S. West, Haematococcus lacustris (GirodChantrans) Rostafinski microalgae species obtained through isolation from the samples we took from Altınapa Dam Pond were exposed to heavy metal solutions and metal uptake ability in waste water treatment was investigated.

\section{MATERIAL AND METHOD}

Sampling, Species Isolation, Cultural Conditions and Species Identification: Samples were taken from Altınapa Dam Lake in May and June 2019. Sediment, plant and stone samples taken from the benthic region of Altınapa Dam Lake were brought to the laboratory under appropriate conditions in lake water with sterile bottles. After, plant and stone samples were washed with distilled water, the samples were taken into a petri dish by scraping.

The preparation for morphological determination was prepared and examined directly under a microscope. For the isolation process, the dilution method was applied to obtain monocultures from mixed samples scraped into the petri dish (Rippka, 1988). In this method, mixed cultures taken from natural habitats were placed in a petri dish and diluted with sterile water. This dilution was continued until the cells were freely visible in one form in the mixture. Then 
each cell was isolated individually by working under an inverted microscope with the help of a pasteur pipette. Once single cells were obtained, the cells were transferred to BG11 medium used for growth. The $\mathrm{pH}$ of the medium was adjusted to 6.8. Cultures were grown at $25^{\circ} \mathrm{C}$ under a fluorescent light intensity of 3000 lux in sterile shake flasks containing $100 \mathrm{~mL}$ of BG-11. It was incubated for 15-20 days in a suitable incubator for photosynthesis on a 12 hour light and 12 hour dark cycle. Then cell numbers, cell layouts and cell shapes were checked. Morphological characterization Prescott, (1973) and John et al., (2002) methods.

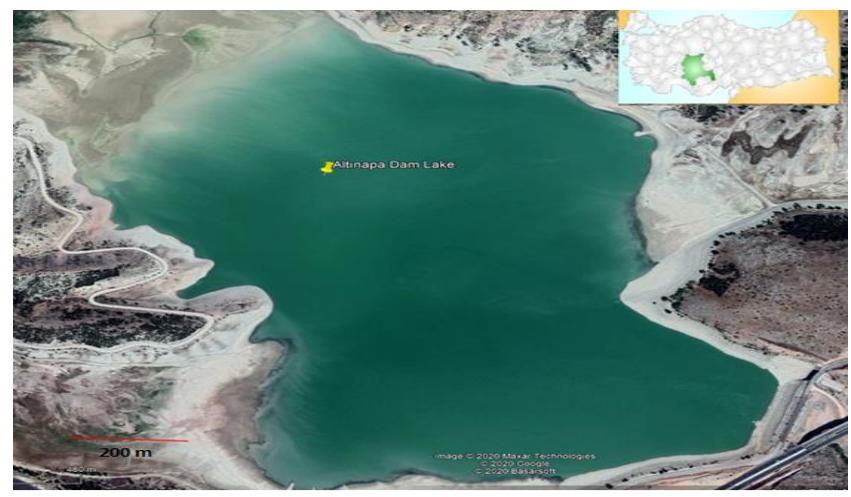

Figure 1. Satellite image of Altınapa Dam Lake.

Heavy Metal Absorption Measurements of Cultured Species: Distilled water of the appropriate $\mathrm{pH}$ value was used for the solution in which the algae will be studied, and a buffer solution was prepared to adjust the $\mathrm{pH}$ of the environment. An appropriate amount of undissolved MnSO4 (Merck) and CuSO4 (Merck) was used to prepare the copper and manganese stock solution $(1000 \mathrm{mg} / \mathrm{L})$. It was mixed with the Britton-Robinson (B-R) buffer solution to make the stock solution suitable. In order to prepare the Britton-Robinson (BR) buffer solution, $2.3 \mathrm{~mL}$ of glacial acetic acid, $2.7 \mathrm{~mL}$ of phosphoric acid and $2.4720 \mathrm{~g}$ of boric acid are added to 1 liter of water and $100 \mathrm{ml}$ of this mixture is added to $2 \mathrm{M} \mathrm{NaOH}$ and the $\mathrm{pH}$ of the stock solution is 2.0 . and between 8.0 (Inam \& Toprak, 2005). Experimental groups were formed by taking $100 \mathrm{ml}$ of algae cultures into flasks. In these experimental groups formed from live algae cultures, the $\mathrm{pH}$ amounts were fixed to $\mathrm{pH} 7.04$ in the Manganese test and to 6.36 in the Copper test. $\mathrm{pH}$ measurements were made with a Hach-Lange brand $\mathrm{pH}$ meter.

Measurements were made at 5, 10, 20, 30, 45, 60, 90 and 120 minutes. At each measurement, $15 \mathrm{ml}$ of algae culture was taken and filtered on Whatman GF / C branded filter paper with a pore opening of $0.125 \mu \mathrm{m}$, and heavy metals in this filtrate were measured in the ICP-OES device.

The formula for the retention efficiency of metals is given below (König-Peter et al., 2015).

$\%$ removal efficiency $=\mathrm{C}_{\mathrm{o}}-\mathrm{C}_{\text {remaining }} / \mathrm{Co} * 100$
$\mathrm{C}_{\mathrm{o}}$ : Origin metal concentration $(\mathrm{mg} / \mathrm{L})$

$\mathrm{C}_{\text {remaining: }}$ Metal concentration remaining in solution at the end of the process $(\mathrm{mg} / \mathrm{L})$

Table 1. Technical information about the device.

\begin{tabular}{ll}
\hline & ICP-OES working conditions \\
\hline Device & ICP-OES (Varian-Vista, Australia)) \\
RF power & $0.7-1.5 \mathrm{~kW}(1.2-1.3 \mathrm{~kW}$ for axial) \\
Plasma gas flow rate (Ar) & $10.5-151 / \mathrm{min}$ (radial) 15 (axial) \\
Auxiliary gas flow rate (Ar) & 1.5, \\
Detection height & $5-12 \mathrm{~mm}$ \\
Copying and reading time & $1-5 \mathrm{~s}(\max , 60 \mathrm{~s})$ \\
Copying & $3 \mathrm{~s}(\max , 100 \mathrm{~s})$ \\
\hline
\end{tabular}

The wavelengths of the elements measured in the device are $\mathrm{Cu} 327.395 \mathrm{~nm}$ and $\mathrm{Mn} 257.610 \mathrm{~nm}$, respectively. The graphs of the statistical analysis showing the $\mathrm{Cu}$ and $\mathrm{Mn}$ absorption capacities of the algae and their removal efficiency were created in the SPSS 21 program.

\section{RESULTS}

To calculate the level of $\mathrm{Cu}$ and $\mathrm{Mn}$ absorption, all three experimental groups were prepared in the same way. $15 \mathrm{ml}$ samples were taken for each measurement from three separate solutions prepared in Scenedesmus circumfusus Hortobágyi, Chlorochytrium paradoxum (G.A.Klebs) G.S. West, Haematococcus lacustris (Girod-Chantrans) Rostafinski species isolated from Altınapa Dam Lake and filtered through filter paper. The samples were taken at 5,10 , 20, 30, 45, 60, 90 and 120. minutes and measurements were performed.

Copper; highly toxic to fish, invertebrates and amphibians. It can reduce the growth of aquatic organisms such as fish and damage the gill and kidney. $\mathrm{Cu}$ is an essential trace element for humans, but high levels of $\mathrm{Cu}$ or $\mathrm{Cu}$ poisoning can cause liver cirrhosis (liver diseases) and, in extreme cases, death of humans (Kibria, 2016).

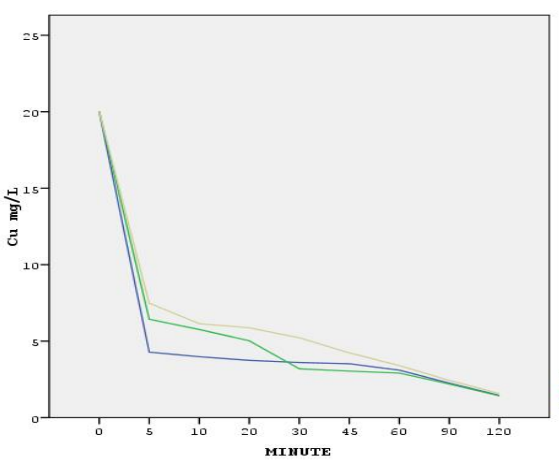

Figure 2. $\mathrm{Cu}$ absorption capacity of algae.

$\mathrm{Cu}$ element absorption capacities of algae are given in Table 2. In Scenedesmus circumfusus Hortobágyi, it was found to be $4.28 \mathrm{mg} / \mathrm{L}, 3.98 \mathrm{mg} / \mathrm{L}, 3.74 \mathrm{mg} / \mathrm{L}, 3.6 \mathrm{mg} / \mathrm{L}$, $3.52 \mathrm{mg} / \mathrm{L}, 3.1 \mathrm{mg} / \mathrm{L}, 2.25 \mathrm{mg} / \mathrm{L}$ and $1.45 \mathrm{mg} / \mathrm{L}$ respectively. Chlorochytrium paradoxum (G.A.Klebs) G.S.West species $6.43 \mathrm{mg} / \mathrm{L}, 5.76 \mathrm{mg} / \mathrm{L}, 5.02 \mathrm{mg} / \mathrm{L}, 3.19 \mathrm{mg} / \mathrm{L}, 3.04 \mathrm{mg} / \mathrm{L}$, $2.91 \mathrm{mg} / \mathrm{L}, 2.19 \mathrm{mg} / \mathrm{L}$ ve $1.42 \mathrm{mg} / \mathrm{L}^{\prime}$ dir. $\mathrm{Cu}$ was found to be $6.43 \mathrm{mg} / \mathrm{L}, 5.76 \mathrm{mg} / \mathrm{L}, 5.02 \mathrm{mg} / \mathrm{L}, 3.19 \mathrm{mg} / \mathrm{L}, 3.04 \mathrm{mg} / \mathrm{L}$, 
$2.91 \mathrm{mg} / \mathrm{L}, \quad 2.19 \mathrm{mg} / \mathrm{L}$ and $1.42 \mathrm{mg} / \mathrm{L}$ respectively Chlorochytrium paradoxum (G.A.Klebs) G.S.West. Copper element in Haematococcus lacustris (Girod-Chantrans)
Rostafinski species $7.48 \mathrm{mg} / \mathrm{L}, 6.14 \mathrm{mg} / \mathrm{L}, 5.87 \mathrm{mg} / \mathrm{L}, 5.22$ $\mathrm{mg} / \mathrm{L}, 4.23 \mathrm{mg} / \mathrm{L}, 3.4 \mathrm{mg} / \mathrm{L}, 2.43 \mathrm{mg} / \mathrm{L}$ and $1.57 \mathrm{mg} / \mathrm{L}$ (Table 2).

Table 2. Algae $\mathrm{Mn}$ and $\mathrm{Cu}$ element absorption capacity $(\mathrm{mg} / \mathrm{L})$.

\begin{tabular}{|c|c|c|c|c|c|c|c|c|c|c|}
\hline & & $\mathbf{0}^{\prime}$ & $5^{\prime}$ & $10^{\prime}$ & $20^{\prime}$ & $30^{\prime}$ & $45^{\prime}$ & $60^{\prime}$ & $90^{\prime}$ & $120^{\prime}$ \\
\hline \multirow[t]{2}{*}{ S.C. } & Mn & 48,24 & 40,63 & 29,35 & 20,74 & 18,57 & 17,44 & 16,32 & 16,01 & 14,45 \\
\hline & $\mathrm{Cu}$ & 20,02 & 4,28 & 3,98 & 3,74 & 3,6 & 3,52 & 3,1 & 2,25 & 1,45 \\
\hline \multirow[t]{2}{*}{ C.P. } & Mn & 48,24 & 43,17 & 38,68 & 29,64 & 29,08 & 28,53 & 27,11 & 26,64 & 25,58 \\
\hline & $\mathrm{Cu}$ & 20,02 & 6,43 & 5,76 & 5,02 & 3,19 & 3,04 & 2,91 & 2,19 & 1,42 \\
\hline \multirow[t]{2}{*}{ H.L } & Mn & 48,24 & 45,09 & 40,91 & 32,26 & 31,82 & 30,27 & 29,91 & 29,56 & 28,98 \\
\hline & $\mathrm{Cu}$ & 20,02 & 7,48 & 6,14 & 5,87 & 5,22 & 4,23 & 3,4 & 2,43 & 1,57 \\
\hline
\end{tabular}

S.C.: Scenedesmus circumfusus Hortobágyi C.P.: Chlorochytrium paradoxum (G.A.Klebs) G.S.West H.L.: Haematococcus lacustris (Girod-Chantrans) Rostafinski.

The highest uptake was seen at 5 minutes in copper-added algae cultures. Scenedesmus circumfusus Hortobágyi took the heavy metal in the environment with $79 \%$. All species have reached absorption capacities close to each other. The retention efficiency of all three algae reached $92 \%$ after 120 minutes (Figure 3).

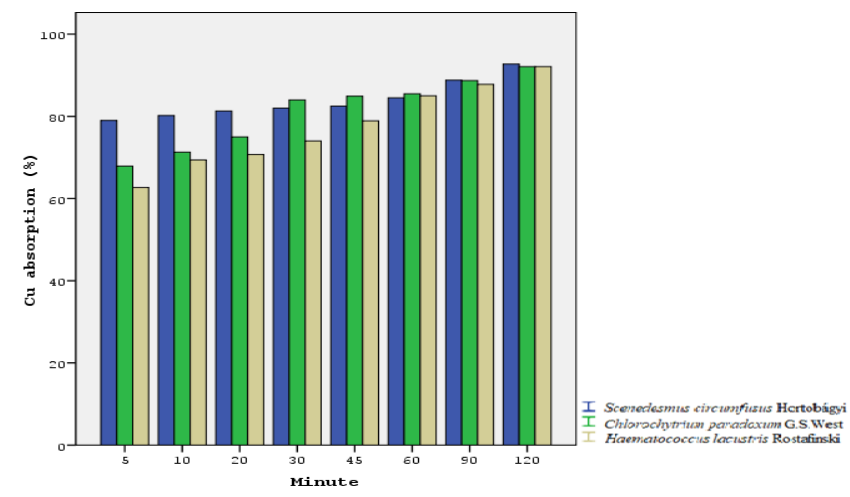

Figure 3. $\mathrm{Cu}$ retention efficiency of algae over time (\%).

It is used in conjunction with aluminum and copper alloys as a component in the manganese material industry and steel production. Manganese dissolves into water as a result of various atmospheric events found naturally in soil and sedimentary masses. It is found in sediments at the bottom of lentic systems and passes from sludge to water in case of a reducing environment. Increasing manganese in water increases the turbidity of the water and the number of bacteria in it, and spoils the taste of the water. Among the discomfort caused by manganese, neurological disorders, weakening of joint and muscle tissue control, respiratory problems are seen (Bradl, 2005; Gürbüz, 2005; Kaptan, 2014, Gümüş \& Akköz, 2020).

Mn element absorption capacities of algae are given in Table 3. In Scenedesmus circumfusus, it was found to be $40.63 \mathrm{mg} / \mathrm{L}, 29.35 \mathrm{mg} / \mathrm{L}, 20.74 \mathrm{mg} / \mathrm{L}, 18.57 \mathrm{mg} / \mathrm{L}$, $17.44 \mathrm{mg} / \mathrm{L}, 16.32 \mathrm{mg} / \mathrm{L}, 16.01 \mathrm{mg} / \mathrm{L}$ and $14.45 \mathrm{mg} / \mathrm{L}$ respectively. Mn was found to be $43.17 \mathrm{mg} / \mathrm{L}, 38.68 \mathrm{mg} / \mathrm{L}$, $29.64 \mathrm{mg} / \mathrm{L}, 29,08 \mathrm{mg} / \mathrm{L}, 28,53 \mathrm{mg} / \mathrm{L}, 27,11 \mathrm{mg} / \mathrm{L}, 26,64$ $\mathrm{mg} / \mathrm{L}$ and $25,58 \mathrm{mg} / \mathrm{L}$, respectively in Chlorochytrium paradoxum. In Haematococcus lacustris, it was determined as $45,09 \mathrm{mg} / \mathrm{L}, 40.91 \mathrm{mg} / \mathrm{L}, 32.26 \mathrm{mg} / \mathrm{L}, 31.82$ $\mathrm{mg} / \mathrm{L}, 30.27 \mathrm{mg} / \mathrm{L}, 29.91 \mathrm{mg} / \mathrm{L}, 29.56 \mathrm{mg} / \mathrm{L}$ and 28.98 $\mathrm{mg} / \mathrm{L}$ respectively (Table 2 ).

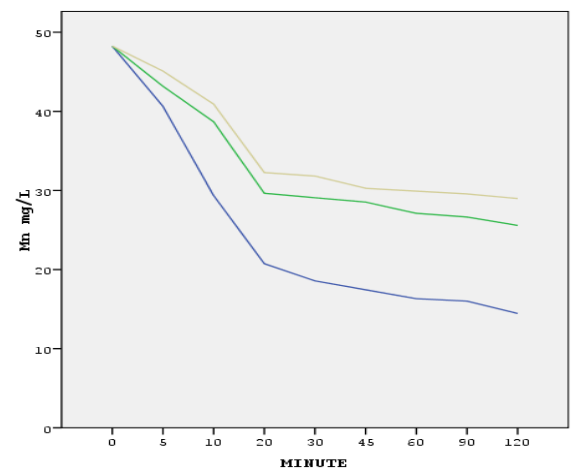

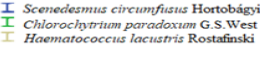

Figure 4. Mn absorption capacity of algae.

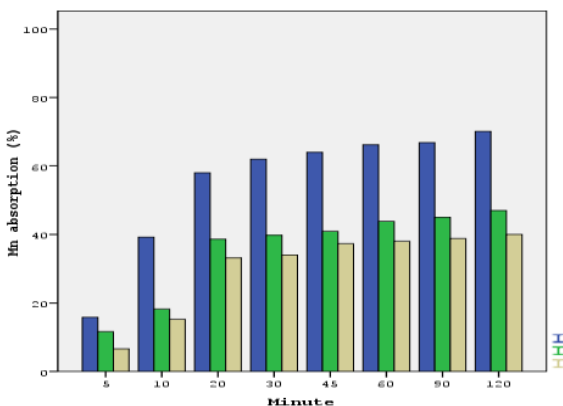

Figure 5. Mn retention efficiency of algae over time (\%).

The algae cultures with added manganese have the highest intake in all three species 30 minute has also been seen. Adhesion efficiency reached $70 \%$ in Scenedesmus circumfusus Hortobágyi species, $47 \%$ in Chlorochytrium paradoxum (G.A.Klebs) species, and 40\% in Haematococcus lacustris (Girod-Chantrans) Rostafinski species after 120 minutes (Figure 5). Manganese-added algae cultures could not reach the absorption capacity of copper-added algae cultures in all three species.

\section{DISCUSSION}

In the biosorption process, obtaining maximum efficiency with minimum biosorbent is important in terms of ease of operation, cost and duration. Biosorption method can be recommended as an easy method with its applicability to metal removal from wastewater compared 
to other methods, its suitability to the biological environment, being effective, economical and applied (Şentürk \& Yıldız, 2018a). Especially algae have come to the fore in recent years.

Gokhale et al., (2008) reported that Cr (VI) ion was adsorbed around $50 \%$ in the first 5 minutes in $\mathrm{S}$. platensis. In our study, $\mathrm{Cu}$ metal was found to be above $60 \%$ in all three algae species.

In their study by Şentürk \& Yıldız, (2018a), the average retention efficiency of $C$. vulgaris for $\mathrm{Cu}$ and $\mathrm{Mn}$ was $87-95 \%$ and $6-56 \%$, respectively. These results are consistent with the algae in this study $\mathrm{Cu}$ and $\mathrm{Mn}$ retention yields. It shows that manganese and copper in the environment are taken up by two algae and that heavy metals are stored in cell components or specific metal binding proteins.

Elmac1 et al., (2005) investigated the biosorption of dried Chara, Cladaphora and Chlorella species in diluted solutions of $\mathrm{Zn}, \mathrm{Cd}$, Co and remozal Turkish-G dyestuff and it was found that these three species could be used in heavy metal removal. In the other study, the dry mass, immobilized living and heat inactivated Oscillatoria sp. When the Cd heavy metal removal of the species is examined, immobilized living Oscillatoria sp. H1 showed the highest biosorption capacity compared to dry mass and inactive Oscillatoria (Katırcıoğlu et al., 2008)

Karaca, (2008) measured the heavy metal biosorption capacities of different algae species in water, and Oocystis sp. was found to be the algae species with the highest absorption capacity after Dunaliella salina.

In a similar study, Terry \& Stone, (2002) evaluated the biosorption using Scenedesmus abundans in waters contaminated with $\mathrm{Cu}$ and $\mathrm{Cd}$. In this study, Scenedesmus circumfusus Hortobágyi species performed better biosorption.

Considering the results of their study, Şentürk \& Yildiz, (2018b) revealed that Chlorella and Scenedesmus cells are effective adsorbents in removing four heavy metals, especially $\mathrm{Cu}^{+2}$ ions from aqueous solutions, due to the high efficiency of $\mathrm{Cu}$ adsorption. The results of these reports were found to be consistent with the findings obtained in our study.

Akköz et al., (2013) examined the Cd (II) biosorption capacities in their study. They found that the $\mathrm{Cd}$ absorption capacity of Oocystis solitaria species was higher than that of Scenedesmus quadricauda species.

As a result of the measurements, it was seen that the Mn absorption capacity of Scenedesmus circumfusus Hortobágyi species was higher than Chlorochytrium paradoxum (G.A.Klebs) G.S.West, Haematococcus lacustris (Girod-Chantrans) Rostafinski) species. As a result, Scenedesmus circumfusus Hortobágyi species was found to be more useful in heavy metal removal from industrial wastewater.

The results we obtained in this study, Yong et al., (1997) shows that the effect of $\mathrm{Cu}$ accumulation in Scenedesmus quadricauda increases depending on the concentration, and Yan \& Pan, (2002) in Scenedesmus obliguus algae are rapidly absorbed by the algae of $\mathrm{Cu}, \mathrm{Zn}$ and $\mathrm{Cd}$.

Studies show that the biosorption capacity increases with increasing atomic number (Akçelik, 2008; Özer \& Özer, 2003). The atomic numbers of the $\mathrm{Cu}$ (II) and $\mathrm{Pb}$ (II) ions are ${ }^{29} \mathrm{Cu}>{ }^{25} \mathrm{Mn}$. According to the data of our study, it can be said that the biosorption capacity increases with increasing atomic number.

Akköz et al., (2013) reported that heavy metal storage levels may vary among algae species. Similar results were observed in the copper deposition in Scenedesmus circumfusus Hortobágyi cells, and these results suggest that manganese and copper in the environment are constantly absorbed by two algae species and heavy metals are stored in cellular components or special metal binding proteins.

\section{CONCLUSION}

In this study, it has not been studied for longer periods for $\mathrm{Cu}$ and $\mathrm{Mn}$ because of the stabilization of adsorption after 120 minutes. Using such creatures to purify heavy metals from water systems is much more convenient than other methods in terms of protecting the environment and minimizing side effects. Researching new approaches to removing heavy metals from wastewater, determining the heavy metal absorption capacity of different biological materials will contribute to technologies that do not harm the environment.

In particular, microalgae are beneficial in the elimination of various areas contaminated with inorganic nutrients and heavy metals. For this reason, it would be appropriate to use 3 algae species used in the study as a biosorbent to remove heavy metal from water.

As a result of this study, it has been determined that Scenedesmus circumfusus Hortobágyi, Chlorochytrium paradoxum (G.A.Klebs) G.S.West, Haematococcus lacustris (Girod-Chantrans) Rostafinski species have positive results in the removal of heavy metals in the laboratory environment, so they can be used in this field. It has been determined that these algae can be useful bioremeditors for removing pollutants from wastewater.

\section{ACKNOWLEDGEMENT}

We would like to thanks BAP (Coordination of Scientific Researching Projects) Foundation of Selcuk 
University for financial support (Project number 18401076).

\section{REFERENCES}

Akçelik, Ö. (2008). A Ăır metallerin Saccharomyces cerevisiae mikroorganizmastyla biyosorpsiyonunun ortam koşullarına bağll olarak incelenmesi. Yüksek Lisans Tezi, Gazi Üniversitesi, Fen Bilimleri Enstitüsü, Ankara, 229s.

Akköz, C., Öztürk, B.Y. \& Aşıkkutlu, B. (2013). Removal of cadmium (II) ion from aqueous system by dry biomass, live and heat-inactivated Scenedesmus quadricauda isolated from fresh water (Apa Dam Lake). Journal of Applied Biological Sciences, 7(2), 54-56.

Bradl, H. (2005). Heavy metals in the environment: origin, interaction and remediation, Academic Press, $269 \mathrm{p}$.

Cheng, S.Y., Show, P.L., Lau, B.F., Chang, J.S. \& Ling, T.C. (2019). New prospects for modified algae in heavy metal adsorption. Trends in Biotechnology, 37(11), 1255-1268. Doi: 10.1016/j.tibtech.2019.04.007

Dora, S.L., Maiti, S.K., Tiwary, R.K. \& Anshumali, A. (2010). Algae as an indicator of river water pollution- a review. The Bioscan, 2, 413-422.

Çoğun, H.Y. \& Kargın, F. (2020). Cyprinus carpio'da Bakırın Solungaç Dokusunda Birikimi ve $\mathrm{Na} / \mathrm{K}$ İyonDüzeylerine Etkisi. Anadolu Çev. ve Hay. Dergisi, 5(3), 313-317. DOI: $10.35229 /$ jaes. 749347

Elmacı, A., Yonar, T., Özengin, N. \& Türkoğlu, H. (2005). Zn (II), Cd (II), Co (II) ve Remazol Turkish Blue-G boyar maddesinin sulu çözeltilerinde kurutulmuş Chara sp., Cladophora sp. ve Chlorella sp. türleri ile biyosorpsiyonun araştırılması. Ekoloji, 14(55), 24-31.

Gemici, B.T., Yücedağ, C., Karakoç, E. \& Algur, D. (2015). Kuyu suyunda bazı kalite parametrelerinin belirlenmesi: Bartın örneği. Mehmet Akif Ersoy Üniversitesi Fen Bilimleri Enstitüsü Dergisi, 6(1), 18-23.

Gokhale S.V., Jyoti K.K. \& Lele S.S. (2008). Kinetic and equilibrium modeling of chromium (VI) biosorption on fresh and spent Spirulina platensis/Chlorella vulgaris biomass. Bioresource Technology, 99(9), 3600-3608. DOI: 10.1016/j.biortech.2007.07.039

Gomes, P. I. \& Asaeda, T. (2013). Phytoremediation of heavy metals by calcifying macro-algae (Nitella pseudoflabellata): implications of redox insensitive end products. Chemosphere, 92, 13281334. DOI: 10.1016/j.chemosphere.2013.05.043

Gümüş, N.E. \& Akköz, C. (2020). Eber gölü (Afyonkarahisar) su kalitesinin araştırılması. Journal of Limnology and Freshwater Fisheries Research, 6(2), 153-163. DOI: $0.17216 /$ limnofish.638567
Gürbüz, B. (2005). Çıldır Gölü'nde avlanan Tatlısu kefali [Leuciscus cephalus (Linnaeus, 1758)] ve Brylkl balıklarda [Barbus plebejus lacerta (Bonaparte, 1832)] bazı ă̆ır metallerin derişim düzeylerinin incelenmesi. Yüksek Lisans Tezi, Kafkas Üniversitesi, Fen Bilimleri Enstitüsü, Kars, 61s.

Inam, R. \& Toprak, C. (2005). Polarographic determination of some toxic trace elements in fish muscles. Fresenius Environmental Bulletin, 14(6), 489-493.

John, D.M., Whitton, B.A. \& Brook, A.J. (2002). The freshwater algal flora of the British Isles: An identification guide to freshwater and terrestrial algae. Cambridge University Press, 702p.

Karaca, M. (2008). Biosorption of aqueus $\mathrm{Pb}^{2+}, \mathrm{Cd}^{2+}$, and $\mathrm{Ni}^{2+}$ ions by Dunaliella salina, Oocystis sp., Porphyridium cruentum, and Scenedesmus protuberans prior to atomic spectrometric determination. Master's thesis, İzmir Institute of Technology, İzmir, 95p.

Katırcıoğlu, H., Aslım, B., Türker, A.R., Atıcı, T. \& Beyatl,, Y. (2008). Removal of cadmium (II) ion from aqueous system by dry biomass, immobilized live and heat-inactivated Oscillatoria sp. H1 isolated from freshwater (Mogan Lake). Bioresource Technology, 99(10), 4185-4191. DOI: 10.1016/j.biortech.2007.08.068

Kaptan, H. (2014), Eğirdir Gölü (Isparta)'nün suyunda, sedimentinde ve gölde yaşayan sazan (Cyprinus carpio l., 1758)' in bazı doku ve organlarındaki ă̆ır metal düzeylerinin belirlenmes. Yüksek Lisans Tezi, Süleyman Demirel Üniversitesi, Fen Bilimleri Enstitüsü, Isparta, 88s.

Kibria, G. (2016). Trace metals/heavy metals and its impact on environment, biodiversity and human health- $A$ short review. 5p. DOI: 10.13140/RG. 2.1. 3102.2568 .

Knezevic, D. (2016). Unicellular Algae from the Genus Chlorella Grown Under Various ConditionsPotential for Use as Feed. Master Thesis, Norwegian University, Oslo, 41p.

König-Peter, A., Ferenc, K., Felinger, A. \& Pernyeszi, T. (2015). Biosorption characteristics of Spirulina and Chlorella cells for the accumulation of heavy metals. Journal of the Serbian Chemical Society, 80(3), 407-419. DOI: 10.2298/JSC140321060P

Nazal, K. (2019). Marine algae bioadsorbents for adsorptive removal of heavy metals. In advanced sorption process applications. IntechOpen London, United Kingdom, DOI: 10.5772/intechopen. 80850

Noori, R., Berndtsson, R., Hosseinzadeh, M., Adamowski, J.F. \& Abyaneh, M.R. (2018). A critical review on the application of the national sanitation foundation water quality index. Environmental Pollution, 244, 575-587. DOI: 10.1016/j.envpol.2018.10.076

Olal, F.O. (2016). Biosorption of selected heavy metals using green algae, Spirogyra species. Journal of Nature and Science, 6, 22-34. 
Özer, A., \& Özer, D. (2003), Comparative study of the biosorption of $\mathrm{Pb}(\mathrm{II}), \mathrm{Ni}(\mathrm{II})$ and $\mathrm{Cr}(\mathrm{VI})$ ions onto S. cerevisiae: determination of biosorption heats. Journal of Hazardous Materials, B100, 219-229. DOI: 10.1016/S0304-3894(03)00109-2

Poo, K.M., Son, E.B., Chang, J.S., Ren, X., Choi, Y.J. \& Chae, K.J. (2018). Biochars derived from wasted marine macro-algae (Saccharina japonica and Sargassum fusiforme) and their potential for heavy metal removal in aqueous solution. Journal of Environmental Management, 206, 364-372. DOI: 10.1016/j.jenvman.2017.10.056

Prescott, G.W. (1973). Algae of The Western Great Lakes Area. Brown Pub., Dubuque, Lowa.

Richards, S., Dawson, J. \& Stutter, M. (2019). The potential use of natural vs commercial biosorbent material to remediate stream waters by removing heavy metal contaminants. Journal of Environmental Management, 231, 275-281. DOI: 10.1016/j.jenvman.2018.10.019

Rippka, R. (1988). Isolation and purification of cyanobacteria. In L Packer, A Glazer (Eds), Methods in Enzymology, Vol 167. Academic Press, San Diego, 3-27pp.

Sahu, Y.K., Patel, K.S., Martín-Ramos, P., Rudzińska, M., Górnaś, P., Towett, E.K., Martín-Gil, J. \& Tarkowska-Kukuryk, M. (2020). Algal characterization and bioaccumulation of trace elements from polluted water. Environmental Monitoring and Assessment, 192(1), 38. DOI: 10.1007/s10661-019-8001-3

Şentürk, T. \& Yıldız, Ş. (2018a). Bazı esansiyel metallerin Chlorella Vulgaris ile biyolojik arıtımı. Manisa Celal Bayar Üniversitesi Sosyal Bilimler Dergisi, $\quad 16(1), \quad$ 197-207. DOI: 10.18026/cbayarsos.424092

Şentürk, T. \& Yıldız, Ş. (2018b). Quaternary Adsorption Effect of Nickel (II), Antimony (III), Manganese (II) and Copper (II) onto Living Two Green Microalgae. Cumhuriyet Science Journal, 39(2), 439-453. DOI: $10.17776 /$ csj. 434265

Terry, P.A. \& Stone, W. (2002). Biosorption of cadmium and copper contaminated water by Scenedesmus abundans. Chemosphere, 47, 249-255. DOI: 10.1016/S0045-6535(01)00303-4

Yan, H. \& Pan, G. (2002). Toxicity and bioaccumulation of copper in three green microalgal species. Chemosphere, 49(5), 471-476. DOI: 10.1016/S0045-6535(02)00285-0.

Yong, W. K., Sim, K. S., Poong, S.W., Wei, D., Phang, S.M. \& Lim, P.E. (2018). Interactive effects of temperature and copper toxicity on photosynthetic efficiency and metabolic plasticity in Scenedesmus quadricauda (Chlorophyceae). Journal of Applied Phycology, 30(6), 3029-3041. DOI: 10.1007/s10811-018-1574-3

Yu, K.L., Lau, B.F., Show, P.L., Ong, H.C., Ling, T.C., Chen, W.H., Ng, E.P. \& Chang, J.S. (2017). Recent developments on algal biochar production and characterization. Bioresource Technology. 246, 2-11. DOI: 10.1016/j.biortech.2017.08.009 